\title{
Macrobenthic Faunal Abundance, Distribution and Diversity in the Bakkhali River, East Coast of Bangladesh
}

\author{
Md. Mozammal Haque ${ }^{1}$, Abu Sayed Muhammad Sharif ${ }^{2}$, Md. Kawser Ahmed ${ }^{13}$, Seema Rani ${ }^{3}$, Md. \\ Habibur Rahman Molla 4 and Makidul Islam Khan ${ }^{3}$ \\ ${ }^{1}$ Department of Oceanography, University of Dhaka, Dhaka 1000, Bangladesh \\ ${ }^{2}$ Bangladesh Oceanographic Research Institute, Cox’s Bazar, Bangladesh \\ ${ }^{3}$ International Centre for Ocean Governance, Faculty of Earth and Environmental Sciences, University of Dhaka, Dhaka, Bangladesh \\ ${ }^{4}$ Department of Biology, Faculty of Science, King Abdulaziz University, Jeddah, Kingdom of Saudi Arabia
}

Manuscript received: 24 April 2021; accepted for publication: 22 August 2021

\begin{abstract}
The study aimed to assess the macrobenthos abundance and distribution from the Bakkhali River, East Coast of Bangladesh. Macrobenthic and water samples were collected from the upper, middle and lower part of the river during post-monsoon. Several indices were used to find macrobenthos abundance and distribution and their correlation with water parameters were also assessed. Present study identified a total of 628 macrobenthos individuals representing 10 major taxa at three stations where 9 taxa were reported in both upper and middle parts whereas only 7 taxa were observed at lower stream of the river. The highest abundance of macrobenthos $\left(301.04\right.$ indivs $\left./ \mathrm{m}^{2}\right)$ was recorded at the lower stream and the lowest abundance $\left(166.3\right.$ indivs $\left./ \mathrm{m}^{2}\right)$ was found at the upper part of the river. Macrobenthos distribution showed that the number of Oligochaetes was higher (220 indivs) followed by Nemertinas (169 indivs) and Polychaetes (145 indivs). Study findings reveal that macrobenthos abundance and distribution were comparatively higher at the lower stream than the upper and middle part because of higher level of pollution and sendimentation rate that might influence the macrobenthos abundance and diversity in the upper and middle part. The study also found macrobenthos abundance was proportionally increased with increasing salinity and $\mathrm{p}^{\mathrm{H}}$. However, macrobenthos abundance was decreased with increasing temperature. Simpson index (D) was the highest (0.32) at middle and lower part and the lowest (0.23) was in the upper part. Shannon-wiener index (H) was also higher (1.68) at the upper part. Both the indices showed higher diversity at the upper part because of having maximum taxa in the station. Based on the $\mathrm{H}$ value, this study reported that Bakkhali River was moderately polluted since $\mathrm{H}$ value was in the range of 1.44 to 1.68 . These might be because of anthropogenic sources of pollution in the vicinity of the river. This study suggests to take proper management strategies to control aquatic pollution and conserve aquatic biodiversity.
\end{abstract}

Keywords: Macrobenthos, Distribution pattern, Diversity, Bakkhali River, East Coast of Bangladesh

\section{INTRODUCTION}

Macrobenthos of any aquatic ecosystem are widely considered as the best bio-indicator to evaluate and monitor the environmental situations of an ecosystem more efficiently than physico-chemical factors of water and sediment (McLusky and Elliott, 2004). They usually live at the bottom of any waterbody because of their sedentary and sessile nature. However, macrobenthic organisms of any aquatic body might be influenced by physicochemical factors of the surrounding environment where they reside. That is why macrobenthic organisms help to understand the changing pattern of any aquatic environments providing more specific

Corresponding author: Md. Mozammal Haque

Email: mozammal006@gmail.com

DOI: https://doi.org/10.3329/dujees.v10i1.56279 information regarding the water quality, pollution level, nutrients availability, etc. (Ikomi et al. 2005).

Macrobenthic organisms play a vital role as a transitional source in food webs since they can control sediment properties and regulate nutrient cycles by mobilizing and rearticulating sediments and organic substances in an aquatic ecosystem (Snelgrove, 1998). However, excessive nutrient influx and changes of soil parameters might result in short- or long- term shifts in macrobenthos abundance and distribution of any aquatic body (Aura et al., 2011). Moreover, fluctuation of physico-chemical parameters of aquatic environment such as temperature changes, salinity deviation, $\mathrm{pH}$ alterations, pressure gradients, density differences, organic matters, siltation rate, toxicity or pollution level and bathymetry topographies could also restrict macrobenthos composition, abundance, and distribution (Pearson, 1975; Coleman et al., 2007). 
The Bakkhali River, one of the most important rivers in Cox's Bazar, is situated at the south-eastern coastal area of the Bay of Bengal. Several small creeks that are originated from the south-eastern mountains of Mizoram province of India joined at the Naikhongchhari of Bandarban district and then formed the Bakkhali River. It runs through the Naikhongchhari and Ramu of Cox's Bazar and drains in the mouth of the Moheshkhali channel of the Bay of Bengal. This river is comparatively bigger in size $(67 \mathrm{~km})$ than other rivers of the Cox's Bazar (Rashed-Un-Nabi et al. 2011). Upstream of the river is less polluted because of less anthropogenic activities than the lower part that is heavily influenced by anthropogenic and industrial activities including fish harbours, fish processing plants and a large number of fish and shrimp farms (Rashed-UnNabi et al., 2011). Maximum rivers that are located at the urban regions in developing countries become the ultimate endpoints of discharged runoffs from the industries (Suthar et al., 2010) which is very similar in Bangladesh too. As a result, huge amount of organic and inorganic waste products alter the physico-chemical properties of the river and ultimately influence the aquatic biodiversity of the river. Since physocio-chemical properties of any waterbody influence macrobenthos communities, so it is very imperative to evaluate the macrobenthos abundance and distribution in the river.

A few studies were conducted on macrobenthic community structure, abundance and distribution in the Karnaphuli river (Islam et al., 2013), Meghna river estuary at Chairmanghat, Noakhali and the Bakkhali river estuary at Cox's Bazar (Sarker et al., 2016), lower Meghna river estuary (Sharif et al., 2017), Naf river estuary (Noman et al., 2019) and Gomti river, Cumilla (Rahman et al., 2021). Rashed-Un-Nabi et al. (2011) assessed the fish and shellfish assemblage in the Bakkhali River in relation with water parameters. However, there is scare study on macrobenthos abundance and distribution in the Bakkhali River. One study assessed the macrobenthos composition in the Bakkhali river and reported five major macrobenthos taxa in the river (Hena et al., 2012) that it was different from the present study. Macrobenthos abundance and distribution changes over the course of time as physico-chemical parameters might alter the marobenthos distribution. After the study of Hena et al. (2012), there was no study to monitor or assess the macrobenthos communities and their distribution in the river. That is why, this study aims to assess the macrobenthos distribution and abundance in the Bakkhali River in order to represent the current scenario of the macrobenthos communities in the Bakkhali River. In addition, this study also assesses the physico-chemical parameters of surface waters and bottom sediments of the Bakkhali River to understand the environmental impacts on the macrobenthos distributions and abundance in the river.

\section{MATERIALS AND METHODS}

\section{Study area}

The Bakkhali River is one of the most important rivers in Cox's Bazar district that situated at the southeastern coast of the Bay of Bengal in Bangladesh. The river is considered as a main transitional route for Maheskhali channel. In this study, water and macrobenthic samples were collected from three stations i.e. B1: Up Stream (US), B2: Mid-Stream (MS) and B3: Low Stream (LS) of the Bakkhali River during October to December, 2017 (Figure 1). Sampling station's coordinates are shown in Table 1.

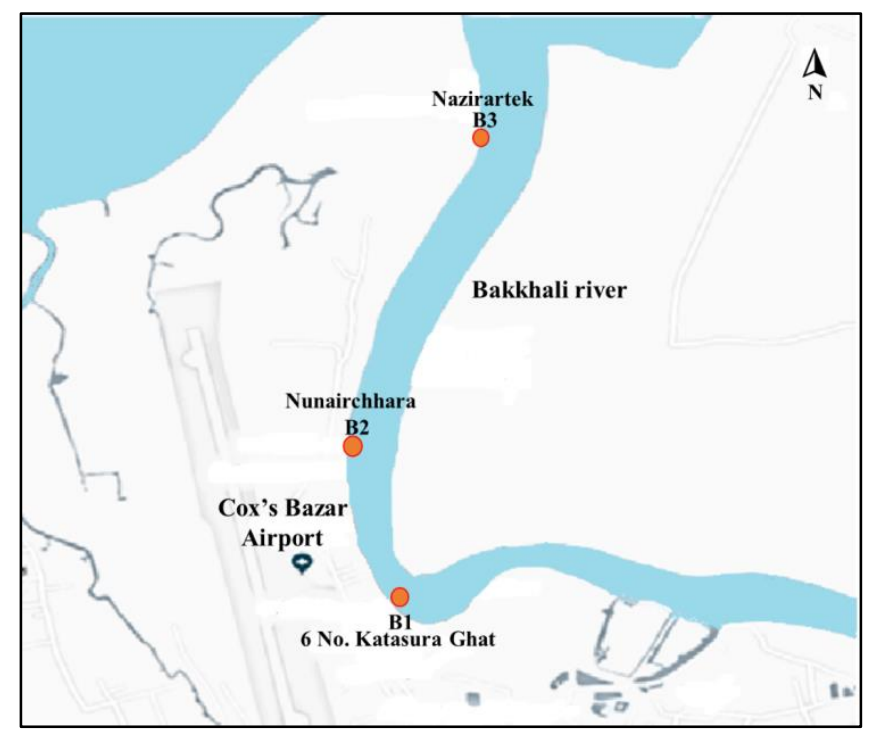

Figure 1. Geographical Locations of Sampling Stations of the Bakkhali River 
Table 1: Sampling Station's Latitudes and Longitudes of the Bakkhali River

\begin{tabular}{|c|c|c|c|c|}
\hline \multirow{2}{*}{$\begin{array}{l}\text { Name of } \\
\text { the rivers }\end{array}$} & \multirow{2}{*}{$\begin{array}{l}\text { Sampling } \\
\text { locations }\end{array}$} & \multirow{2}{*}{$\begin{array}{l}\text { Locations } \\
\text { Name }\end{array}$} & \multicolumn{2}{|c|}{ GPS coordinates } \\
\hline & & & Latitude & Longitude \\
\hline \multirow{3}{*}{$\begin{array}{l}\text { Bakkhali } \\
\text { River }\end{array}$} & B1 (US) & $\begin{array}{l}6 \text { no. Kastura } \\
\text { Ghat }\end{array}$ & $\begin{array}{ll}21^{\circ} & 27^{\prime} \\
0 " \mathrm{~N} & \\
\end{array}$ & $\begin{array}{ll}91^{\circ} & 58^{\prime} \\
8 " \mathrm{E} & \\
\end{array}$ \\
\hline & B2 (MS) & Nunairchhara & $\begin{array}{l}21^{\circ} 27^{\prime} \\
21^{\prime \prime N}\end{array}$ & $\begin{array}{l}91^{\circ} \\
4 " \mathrm{E}\end{array}$ \\
\hline & B3 (LS) & Nazirartek & $\begin{array}{l}21^{\circ} \quad 28^{\prime} \\
19^{\prime \prime} \mathrm{N}\end{array}$ & $\begin{array}{ll}91^{\circ} & 58^{\prime} \\
19^{\prime \prime} \mathrm{E} & \\
\end{array}$ \\
\hline
\end{tabular}

\section{Sample collection and preservation}

The macrobenthic samples were collected on passenger boat from the bottom substrate of each sampling station by using an Ekman grab sampler having an opening mouth of $0.024 \mathrm{~m}^{2}$. The samples were preserved in bottles by using $10 \%$ buffer formalin solution. Water samples were also collected from each of the sampling location with $250 \mathrm{ml}$ plastic bottles. The water and macrobenthic sample containing bottles were pre-washed properly to remove any form of contaminants and preserved temporarily until further analysis.

\section{Samples identification}

The preserved macrobenthic samples were taken to the laboratory for identification purposes. All coarse materials were sorted, counted and identified. The specimens were identified upto various taxa on the basis of the external morphology following the methods of Gosner (1972), Arnold and Birtles (1989) and Belaluzzaman (1995). The physical and chemical parameters of water samples were determined on the spot and the rest were determined in the laboratory.

\section{Data analysis}

All statistical data were analyzed using Microsoft Excel (version-13). Descriptive statistics such as mean, percentage and correlation of macrobenthos with water parameters were conducted in this study. Data were presented in tabular and graphical form. Different diversity indices were calculated using the following formulas:

\section{Taxa richness $(R)$}

The taxa richness or species richness of any ecosystem was built on the numbers of taxa or number of species found in an area or ecological environment. It does not reflect the relative abundance of the species rather articulates the number of species.

\section{Shannon-wiener index $(\mathrm{H})$}

The collected data were pooled together to estimate the Shannon-wiener index to determine species diversity and species evenness. Shannonwiener index and evenness index were calculated following the equations:

$$
\mathrm{H}=-\mathrm{SUM}\left[\left(\mathrm{P}_{\mathrm{i}}\right) \mathrm{x} \ln \left(\mathrm{P}_{\mathrm{i}}\right)\right] \text { and } \mathrm{E}=\mathrm{H} / \mathrm{H}_{\max }
$$

Where,

$\mathrm{Pi}=$ Number of individuals of each species $\mathrm{i} /$ total number of samples

$$
\begin{aligned}
& \mathrm{S}=\text { Total number of species } \\
& \mathrm{H}_{\max }=\text { Maximum diversity possible } \\
& \mathrm{E}=\text { Eveness }=\mathrm{H} / \mathrm{H}_{\max }
\end{aligned}
$$

\section{Margalef's index (d)}

Species richness is the ratio between the total species and the total numbers of individual. It was used to compare one community with another. The index is determined using the following formula:

$$
\begin{aligned}
& \mathrm{d}=\frac{\mathrm{S}-1}{\operatorname{LnN}} \\
& \text { Where, } \\
& \mathrm{d}=\text { Margalef's index } \\
& \mathrm{S}=\text { Number of species in sample } \\
& \text { Ln = log normal } \\
& \mathrm{N}=\text { Total number of individuals in sample }
\end{aligned}
$$

\section{Evenness $(E)$}

Evenness of taxa was calculated by the following formula:

$\mathrm{E}=\mathrm{H} / \ln (\mathrm{R})$

Here,

$\mathrm{H}=$ Shannon-wiener index

$\mathrm{R}=$ Species richness

\section{Simpson index $(D)$}

The Simpson index ranges between 0 and 1, and the greater the value, the greater the sample diversity.

Simpson Index $=\frac{1}{\sum_{i=1}^{S}\left(P_{i}\right)^{2}}$

Where,

$\mathrm{P}=\mathrm{n} / \mathrm{N}$ 
$\mathrm{n}=$ Individuals of one particular species

$\mathrm{N}=$ Total number of individuals

$\Sigma=$ Sum of the calculations

$\mathrm{S}=$ Number of species.

\section{RESULTS AND DISCUSSION}

\section{Macrobenthic abundance and distribution}

In this study, a total of 10 major taxa were identified at three stations of the Bakkhali River. The highest abundance was recorded at low stream (301.04 indivs $/ \mathrm{m}^{2}$ ) and the lowest abundance was found at upstream (166.3 indivs $/ \mathrm{m}^{2}$ ) (Table 2). Different taxanomic dominance variations were found at different streams. Maximum 9 taxa were reported in both upper and middle streams, whereas, minimum 7 taxa were found in lower stream. However, Hena et al. (2012) and Sarkar et al. (2016) reported maximum 5 macrobenthos taxa in the Bakkhali River that is not in line with the present study. These might be because of sampling differences or shifting of macrobenthos organisms in the river from other sources. Among three stations, Oligochaete was the most dominant taxa in the upstream (53.68 indivs $/ \mathrm{m}^{2}$ ), whereas, Nemertina and Polychaete were dominated in the midstream $\left(76.84\right.$ indivs $\left./ \mathrm{m}^{2}\right)$ and the low stream (129.47 indivs $/ \mathrm{m}^{2}$ ), respectively. Results revealed that the abundance of macrobenthos was comparatively much higher at lower stream than upper stream of the Bakkhali River which might be because of changing physico-chemical parameters. This study is in line with Hena et al. (2012) and Sarkar et al. (2016) who also reported higher macrobenthos abundance at the lower part of the Bakkhali river. These might be because of higher level of water pollution and sedimentation rate in lower part of the river that might influence the macrobenthos abundance. In addition, lower stream was much productive and diverse zone than upper stream since it's the mixing point between the river and the sea.

Table 2: Taxa-wise Macrobenthos Abundance (indivs $/ \mathrm{m}^{2}$ ) at Three Stations of the Bakkhali River

\begin{tabular}{llll}
\hline \multirow{2}{*}{ Major taxa } & \multicolumn{3}{l}{$\begin{array}{l}\text { Abundance of macrobenthos at different } \\
\text { stations (indivs } / \mathrm{m}^{2} \text { ) }\end{array}$} \\
\cline { 2 - 4 } & $\mathrm{B}_{1}$ & $\mathrm{~B}_{2}$ & $\mathrm{~B}_{3}$ \\
\hline Polychaete & 17.89 & 5.26 & 129.47 \\
\hline Oligochaete & 53.68 & 68.42 & 97.89 \\
\hline Nemertina & 47.37 & 76.84 & 53.68 \\
\hline
\end{tabular}

\begin{tabular}{llll}
\hline Amphipod & 1.05 & 3.16 & - \\
\hline Bivalvia shell & 29.47 & - & - \\
\hline Calanoida & - & 2.11 & 1.05 \\
\hline Crustacean & 5.26 & 3.16 & 8.42 \\
\hline Echinodermata & 1.05 & 2.11 & - \\
\hline Gastropod & 8.42 & 13.68 & 6.32 \\
\hline Platyhelminthes & 2.11 & 7.37 & 4.21 \\
\hline Total & 166.3 & 182.11 & 301.04 \\
\hline
\end{tabular}

In this study, total 628 macrobenthic individuals were recorded from three stations of the Bakkhali River. The number of macrobenthic individuals were recorded higher in Oligochaete (220 indivs), Nemertina (169 indivs) and Polychaete (145 indivs) taxa than rest of the taxa (Table 3). In contrast, the lowest number of macrobenthic individuals were recorded in Calanoida and Echinodermata, and it was 3 individuals for each taxa. Among all the taxa, Oligochaete contained maximum $35.03 \%$ of all indiduals followed by Nemertina (27.91\%), Polychaete (23.09\%), Bivalvia shell (4.46\%), Gastropod (4.29\%), Crustacean (2.55\%), Platyhelminthes (2.07\%), Amphipod (0.64\%), Echinodermata $(0.48 \%)$ and Calanoida $(0.48 \%)$ (Figure 2). However, Hena et al. (2012) and Sarkar et al. (2016) found Bivalvia and Polychaete were the dominated taxa in the Bakkhali River, respectively. But this study is in line with Rahman et al. (2021) who reported Oligochaete $(83 \%)$ was the dominated group in the Gomti River.

Table 3: Macrobenthos Frequency and Mean Distribution at Three Stations of the Bakkhali River

\begin{tabular}{llllll}
\hline \multirow{2}{*}{ Benthos groups } & \multicolumn{2}{l}{$\begin{array}{l}\text { Macrobenthos } \\
\text { frequency (No.) }\end{array}$} & Mean & Total \\
\cline { 2 - 6 } & $B_{1}$ & $B_{2}$ & $B_{3}$ & & \\
\hline Polychaete & 17 & 5 & 123 & 48.33 & 145 \\
\hline Oligochaete & 51 & 65 & 104 & 73.33 & 220 \\
\hline Nemertina & 45 & 73 & 51 & 56.33 & 169 \\
\hline Amphipod & 1 & 3 & - & 1.33 & 4 \\
\hline Bivalvia shell & 28 & - & - & 9.33 & 28 \\
\hline Calanoida & - & 2 & 1 & 1 & 3 \\
\hline Crustacean & 5 & 3 & 8 & 5.33 & 16 \\
\hline Echinodermata & 1 & 2 & - & 1 & 3 \\
\hline Gastropoda & 8 & 13 & 6 & 9 & 27 \\
\hline Platyhelminthes & 2 & 7 & 4 & 4.33 & 13 \\
\hline Total & 158 & 173 & 297 & 209 & 628 \\
\hline
\end{tabular}




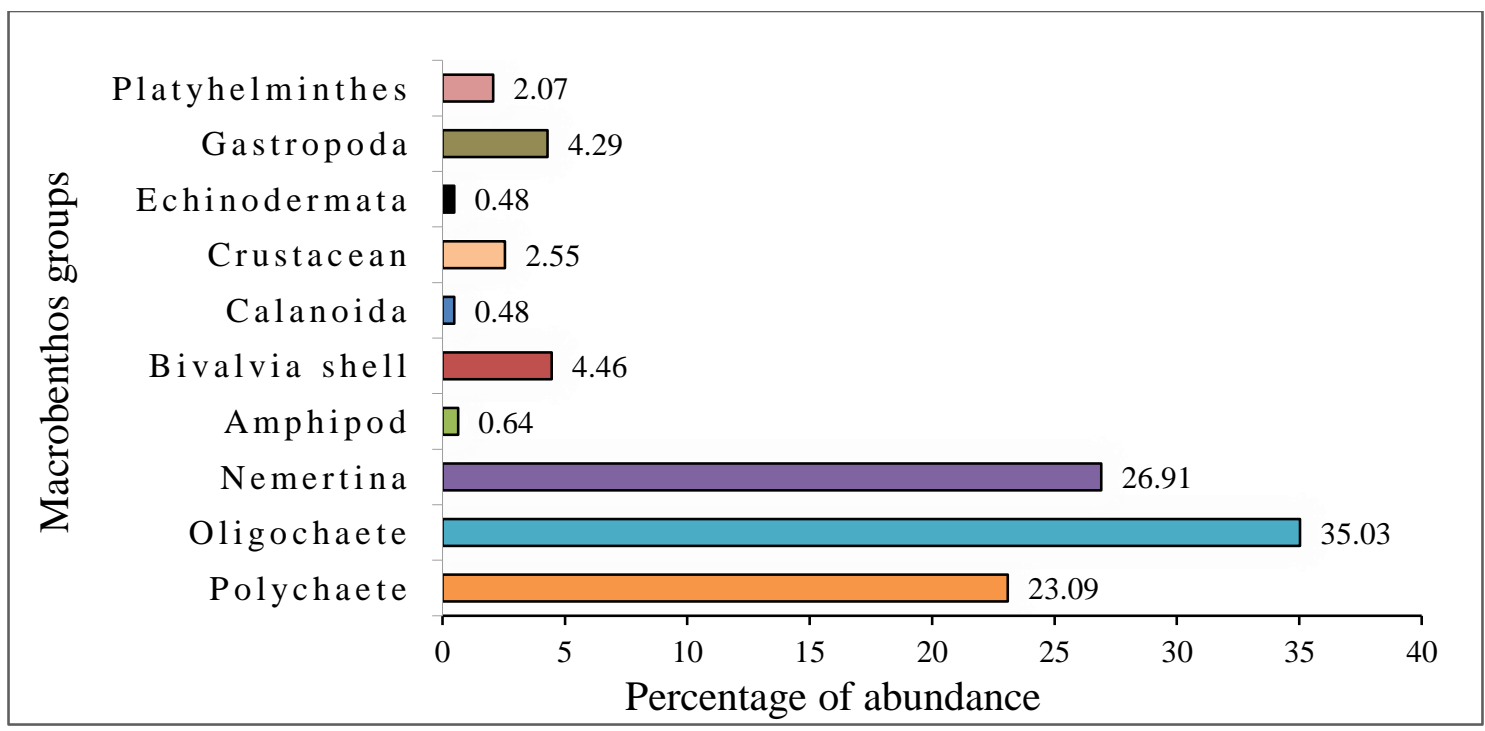

Figure 2: Composition of Macrobenthic Species Distribution in the Bakkhali River

Diversity indices were used to show the significant differences of the macrobenthic abundance and diversity in three stations of the Bakkhali River. The highest value (0.32) of Simpson index (D) was found at stations $B_{2}$ and $B_{3}$ and the lowest value (0.23) was observed at station $B_{1}$ (Table 4). The low value of $\mathrm{D}$ reported that biodiversity of macrobenthos was higher at station $B_{1}$ and $B_{2}$ since each stations showed maximum 9 taxa. As well as Shannon-wiener index value (1.68) also reported higher macrobenthos biodiversoity at station $B_{1}$. Based on the $H$ value, this study reported that Bakkhali River was moderately polluted since $\mathrm{H}$ value was in the range of 1.44-1.68. In general, $\mathrm{H}$ value of any natural waterbody varies from 0 to 5 (Lizhe et al., 2002) and when the $\mathrm{H}$ value ranges in between 1-2, it indicates moderate pollution level. However, $\mathrm{H}$ value less than 1 indicates heavily polluted condition of the aquatic environment while the values above 3 showed stable environment (Wilhm and Dorris, 1966). Hena et al. (2012) reported Bakkhali River was heavily polluted to some extent as $\mathrm{H}$ value was ranged in between 0.65 to 1.04 , whereas, Sarkar et al. (2016) reported it was gently polluted. The present study was in between of them and reported moderate pollution level of the river. The evenness value indicated that macrobenthos were not evenly distributed in all of the three stations since it was less than 1. This study was in line with Sarkar et al. (2016) who also reported $E$ values ranged from 0.73 to 0.85 in the Bakkhali River. However, the present study found a bit higher $\mathrm{E}$ values than Hena et al. (2012). The average diversity values of Shannon index, Evenness, Simpson index and Margalef's index were $1.45,0.71,0.29$ and 1.39 .

Table 4: Macrobenthic Diversity Indices at Three Stations of the Bakkhali River

\begin{tabular}{llllll}
\hline Stations & $\mathbf{B}_{1}$ & $\mathbf{B}_{2}$ & $\mathbf{B}_{3}$ & Mean & $\begin{array}{l}\text { All } \\
\text { Stations }\end{array}$ \\
\hline $\begin{array}{l}\text { Taxa } \\
\text { richness (R) }\end{array}$ & $* 9$ & $* 9$ & 7 & 8.33 & 25 \\
\hline Simpson (D) & 0.23 & $* 0.32$ & $* 0.32$ & 0.29 & 2.05 \\
\hline Shannon (H) & $* 1.68$ & 1.44 & ND & 1.45 & 6.08 \\
\hline Evenness (E) & $* 0.76$ & 0.66 & ND & 0.71 & 2.71 \\
\hline Margalef (d) & $* 1.58$ & 1.55 & 1.05 & 1.39 & 7.26 \\
\hline
\end{tabular}

*Indicates the highest value among the station

\section{Macrobenthos relation with physico-chemical parameters}

Physico-chemical parameters of water were very important to control the abundance and distribution of aquatic organisms. These parameters have a great effect on the existence of the aquatic organisms. This study showed that surface and atmospheric temperature of station $\mathrm{B}_{1}$ was slightly higher than $\mathrm{B}_{2}$ and $\mathrm{B}_{3}$ (Table 5). But, $\mathrm{pH}$ value at station $\mathrm{B}_{1}$ (6.84) was moderately lower than other two stations. The estimated $\mathrm{pH}$ values in this study is in line with Hena et al. (2012) who also reported nearly similar $\mathrm{pH}$ values in the Bakkhali river. However, the salinity value at station $B_{3}(6.30 \mathrm{ppt})$ was very higher than the values of station $B_{1}$ and $B_{2}$. These might be bacuse of mixing of saline water at the mouth of Bakkhali River and Maheshakhali channel when exposed to the Bay of Bengal. In contrast, Sarkar et al. (2016) reported a 
very higher level of salinity (22 ppt) in the Bakkhali River than the present study. This difference might be occurred due to seasonal differences of sampling. Sarkar et al. (2016) collected samples during February to March whereas this study collected samples during Octorber to December. The physico-chemical parameters and the benthic environment of the Bakkhali River has profound impact on the density, distribution and abundance of macrobenthos in the river. The geography and topography of the river might also affect the system.

Table 5: Physico-chemical Parameters of Water of the Three Stations of the Bakkhali River

\begin{tabular}{lllll}
\hline Stations & $\begin{array}{l}\text { Surface } \\
\text { temperature } \\
\left({ }^{\circ} \mathrm{C}\right)\end{array}$ & $\begin{array}{l}\text { Salinity } \\
(\mathrm{ppt})\end{array}$ & $\mathrm{pH}$ & $\begin{array}{l}\text { Atmospheric } \\
\text { temperature } \\
\left({ }^{\circ} \mathrm{C}\right)\end{array}$ \\
\hline $\mathrm{B}_{1}$ & 30 & 0.21 & 6.84 & 31.8 \\
\hline $\mathrm{B}_{2}$ & 29.8 & 0.61 & 6.88 & 30 \\
\hline $\mathrm{B}_{3}$ & 30 & 6.30 & 6.98 & 30.8 \\
\hline
\end{tabular}

The study showed that the salinity has a great impact on the distribution of macrobenthic organisms in the Bakkhali River. Macrobenthos abundance was proportionally increased with increasing salinity
(Figure 3). Maximum macrobenthic density was recorded at low stream where salinity was maximum 6.30 ppt. The findings of Sarkar et al. (2016) and Haque et al. (2020) also supported the present study as they reported diversity of macrobenthos positively correlated with salinity changes in the Bakkhali River and Sangu River, respectively. Self and Jumars (1978) and Perkins (1976) reported that salinity changes might also control the abundance of macrobenthic organisms in the coastal and estuarine region.

Temperature (particularly surface and atmospheric) was the main driven forces to the variations of macrobenthic organism's abundance and distribution. This study showed surface temperature was more or less simillar to all of the stations. The atmospheric temperature was maximum at upstream $\left(31.8^{\circ} \mathrm{C}\right)$ where the macrobenthic abundance was minimum (158 indivs) comparing rest of the streams (Figure 4). Haque et al. (2020) also reported macrobenthos abundances were negatively correlated with temperature changes, though Hena et al. (2012) and Sarkar et al. (2016) did not show any correlation between macrobenthos abundance and temperature changes in the Bakkhali River.

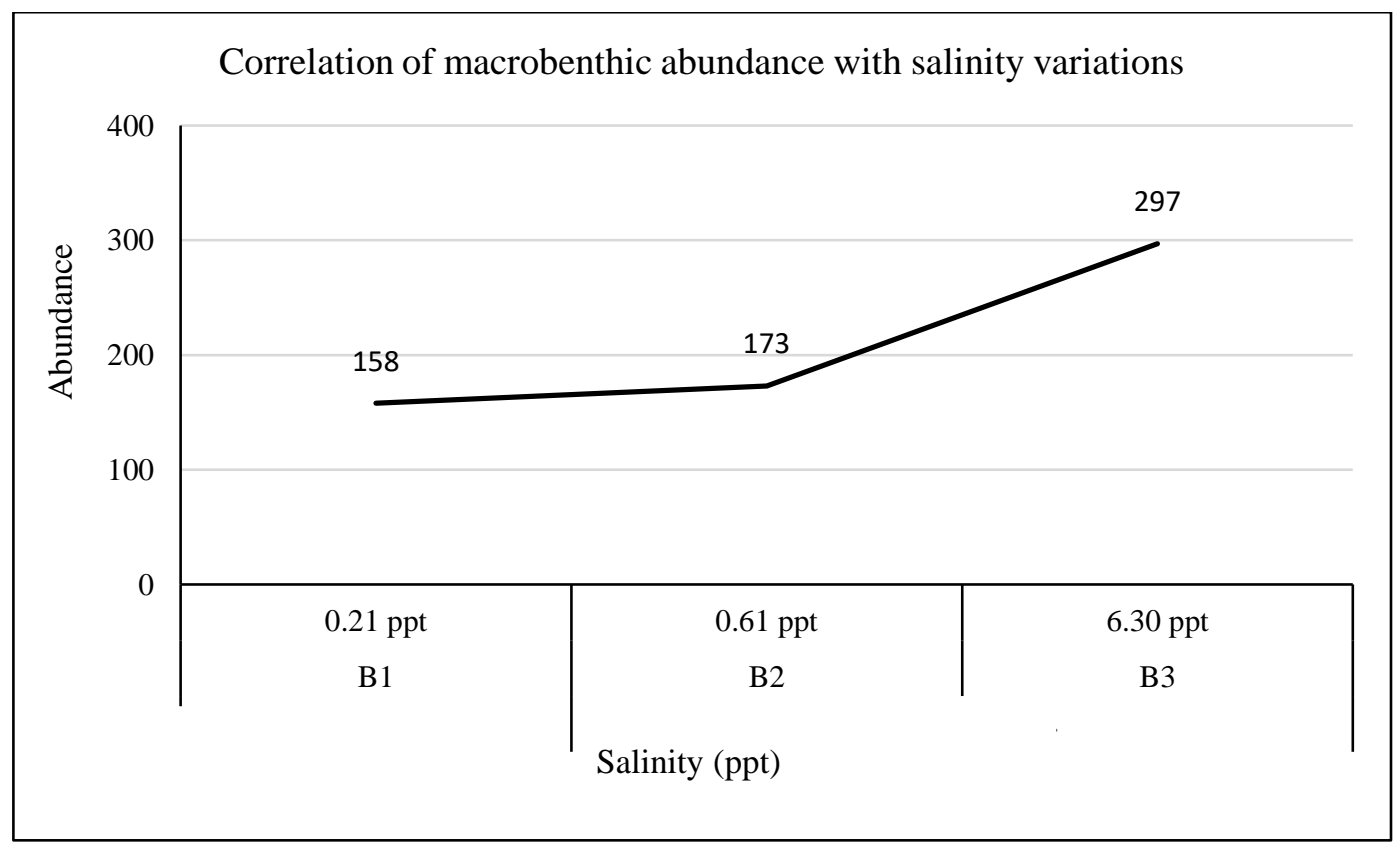

Figure 3: Correlation of Macrobenthic Abundance and Salinity at Three Stations of the Bakkhali River 


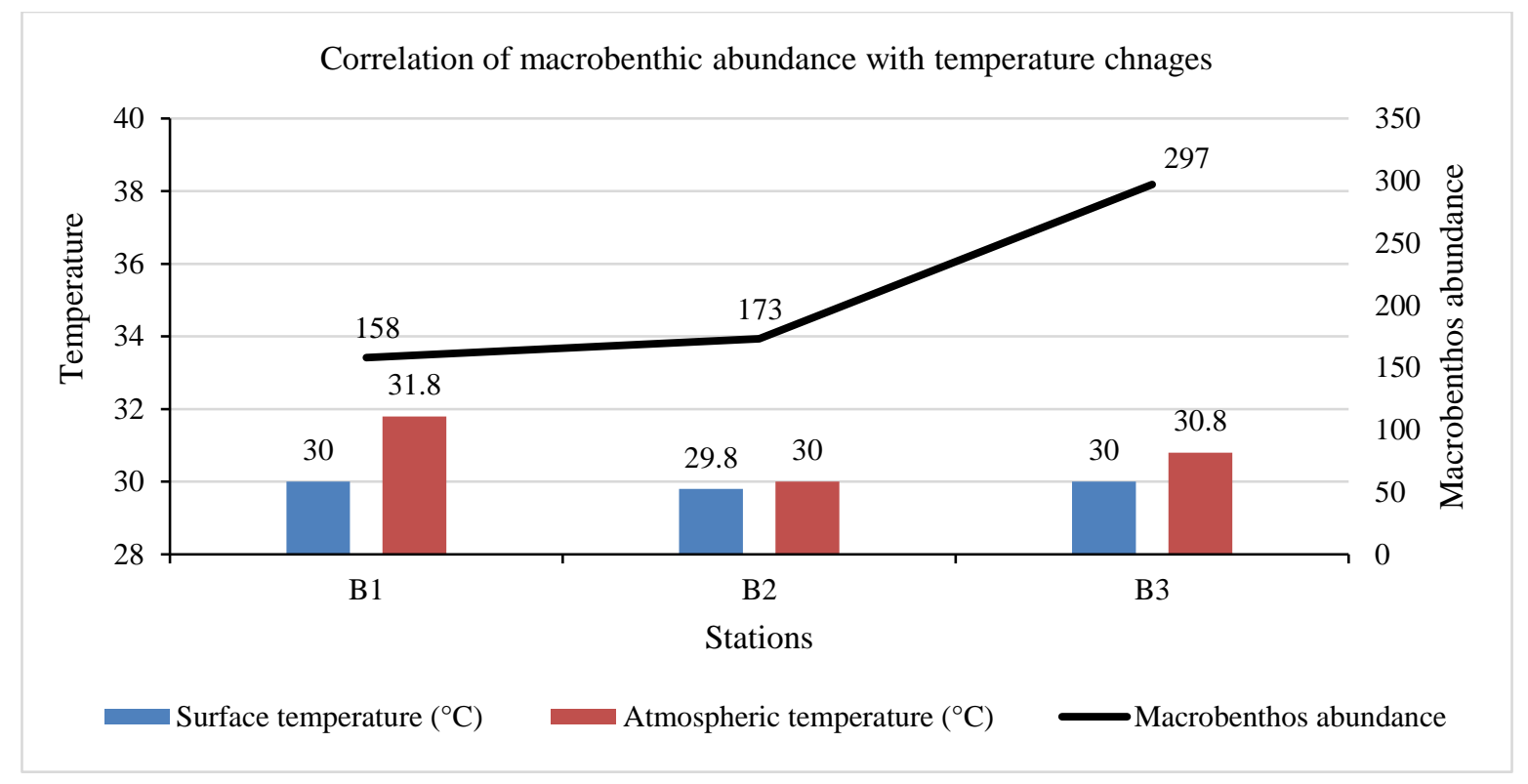

Figure 4: Correlation of Macrobenthic Abundance and Temperature at Three Stations of the Bakkhali River

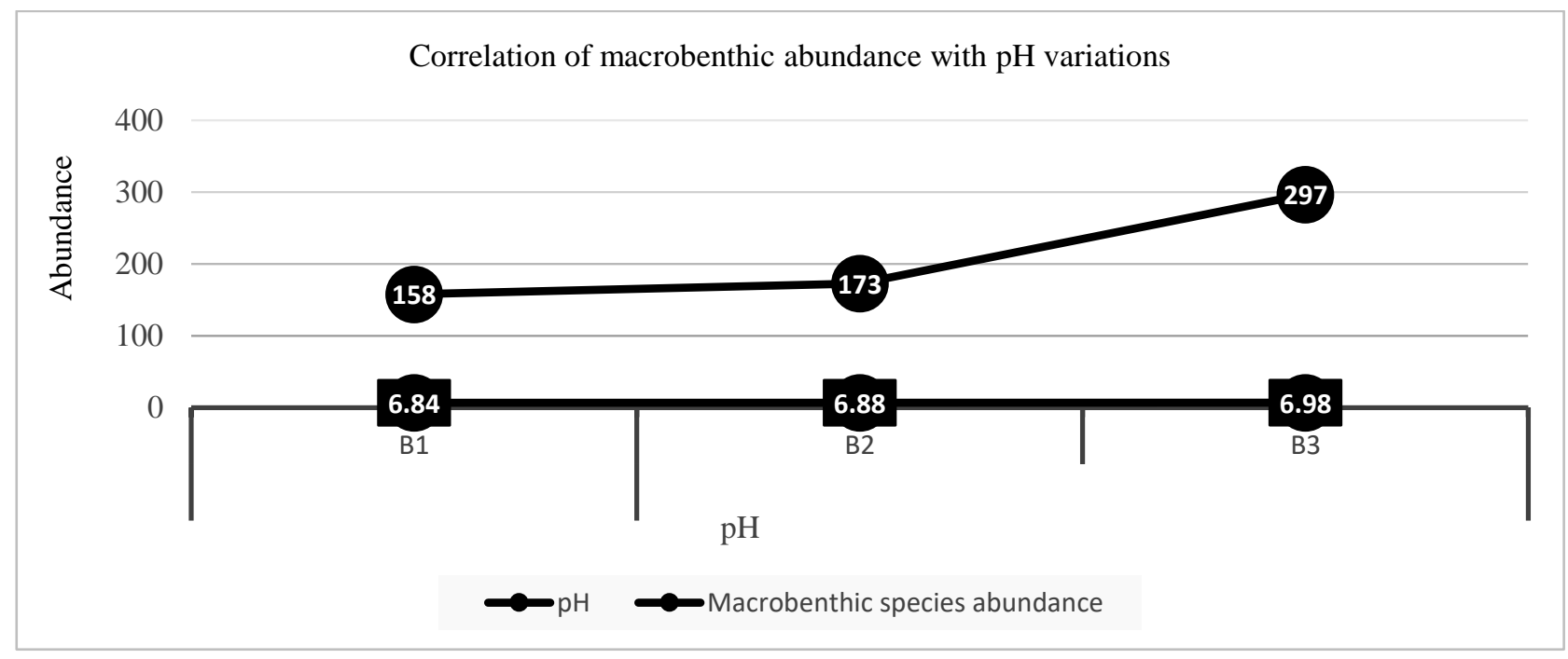

Figure 5: Correlation of Macrobenthic Abundance and pH Changes at Three Stations of the Bakkhali River

The value of $\mathrm{pH}$ is another important parameter of the aquatic ecosystem that influence the aquatic organism's distribution and abundance. This study found that the highest density of macrobenthos was found at low stream where $\mathrm{pH}$ value was maximum 6.98 (Figure 5). It was also supported by Sarkar et al. (2016) in the Bakkhali River and Haque et al. (2020) in the Sangu River that macrobenthos abundances were positively correlated with $\mathrm{pH}$ changes.

\section{CONCLUSIONS}

Macrobenthos are very significant indicators for ecological and bio-monitoring system since they are assorted, sedentary and approachable to the environmental modifications. The current study was aimed to provide a comprehensive knowledge on macrobenthos abundance and distribution and its correlation ship with water parameters of the Bakkhali River. In this study, a total of 10 major taxa were identified and it was reported that macrobenthos abundance and distribution was comparatively higher in lower part of the river than the upper part. The physico-chemical parameters (temperature, salinity and $\mathrm{p}^{\mathrm{H}}$ ) of water and the others benthic situations were found to be responsible for the alterations of the macrobenthic communities' distribution and abundance. Some anthropogenic activities might also be responsible for the changes of macrobenthos 
communities' abundance and distribution in the river. So the present study recommends to monitor the macrobenthos abundance and distribution regularly and take proper management strategies to control aquatic pollution and conserve aquatic biodiversity. This study might help to develop a strategic action plan to monitor macrobenthos abundance and distribution of the rivers.

Acknowledgement: Director General of Bangladesh Oceanographic Research Institute (BORI) is gratefully thanked for his permission to use the biological laboratory of BORI. Md. Abdullah and Sabiha Khanom Nupa of the Department of Oceanography, University of Dhaka are also thanked for their supports to this study.

\section{REFERENCES}

Arnold, P. W. and Birtles, R. A. (1989). Soft sediment marine invertebrates of southeast Aisa and Australia: A guide to identification. Australian Institute of Marine Sciences, Townville, pp. 272

Aura, C. M., Raburu, P. O. and Herrmann, J. (2011). Macroinvertebrates community structure in Rivers Kipkaren and Sosiani, River Nzoia basin, Kenya. Journal of Ecology and the Natural Environment, 3(2): 39-46.

Belaluzzaman, A. M. (1995). Ecology of the Intertidal Macro Benthic Fauna in Cox's Bazar Coastal Area. MSc Thesis, Institute of Marine Sciences, University of Chittagong, Bangladesh.

Coleman, N., Cuff, W., Moverley, J., Gason, A. S. and Heislers, S. (2007). Depth, sediment type, biogeography and high species richness in shallowwater benthos. Marine and Freshwater Research, 58(3): 293-305.

Gosner, K. L. (1972). Guide to identification of marine and estuarine invertebrates: Cape Hatteras to the Bay of Fundy. The Quarterly Review of Biology, 47(1): 112.

Haque, M. M., Sharif, A. S. M., Ahmed, M. K., Anwar, F., Rani, S., Molla, M. H. R. and Khan, M. I. (2020). Distribution and diversity of macrobenthos in Sangu River, Bangladesh. The Dhaka University Journal of Earth and Environmental Sciences, 9(2): 27-34.

Hena, M. K. A., Kohinoor, S. M. S., Siddique, M. A. M., Ismail, J., Idris, M. H. and Amin, S. M. N. (2012). Composition of macrobenthos in the Bakkhali channel system, Cox's Bazar with notes on soil parameter. Pakistan Journal of Biological Sciences, PJBS, 15(13):641-646.

Ikomi, R. B., Arimoro, F. O. and Odihirin, O. K. (2005). Composition, distribution and abundance of macroinvertebrates of the upper reaches of River Ethiope, Delta State, Nigeria. The Zoologist, 3: 68-81.

Islam, M. S., Sikder, M. N. A., Al-Imran, M., Hossain, M. B., Mallick, D. and Morshed, M. M. (2013). Intertidal macrobenthic fauna of the Karnafuli estuary: relations with environmental variables. World Applied Sciences Journal, 21(9): 1366-1373.

Lizhe, C., Li, M., Yang, G., Tianling, Z. and Peng, L. (2002). Analysis on assessing criterion for polluted situation using species diversity index of marine macrofauna. Journal of Xiamen University (Natural Science) 41: 641-646.

McLusky, D. S. and Elliott, M. (2004). The estuarine ecosystem: ecology, threats and management. Third edition. Oxford University Press, Oxford. pp. 214

Noman, M. A., Mamunur, R., Islam, M. S., \& Hossain, M. B. (2019). Spatial and seasonal distribution of intertidal macrobenthos with their biomass and functional feeding guilds in the Naf River estuary, Bangladesh. Journal of Oceanology and Limnology, 37(3): 1010-1023.

Pearson, T. H. (1975). The benthic ecology of Loch Linnhe and Loch Eil, a sea-loch system on the west coast of Scotland. IV. Changes in the benthic fauna attributable to organic enrichment. Journal of Experimental Marine Biology and Ecology, 20 (1), 1-41.

Perkins, E. J. (1976). The biology of estuaries and coastal waters. Academic Press, London and New York. pp. 678.

Rahman, M. A., Ullah, M. A., Hossain, B. M., Kamal, A. H. M., Idris, M. H. and Hossain, M. S. (2021). Diversity, community structure and distribution of macrobenthos from a subtropical river, Bangladesh. Egyptian Journal of Aquatic Biology and Fisheries, 25(2): 707-719.

Rashed-Un-Nabi, M., Al-Mamun, M. A., Ullah, M. H. and Mustafa, M. G. (2011). Temporal and spatial distribution of fish and shrimp assemblage in the Bakkhali river estuary of Bangladesh in relation to some water quality parameters. Marine Biology Research, 7(5): 436-452.

Sarker, M. J., Patwary. M. S. A., Uddin, A. M. M. B., Hasan, M. M., Tanmay, M. H., Kanungo, I. and Parvej, M. R. (2016). Macrobenthic community structure-an approach to assess coastal water pollution in Bangladesh. Fisheries and Aquaculture Journal, 7(1): 157.

Self, R. F. L. and Jumars, P. A. (1978). New resource axes for deposit feeders. Journal of Marine Research, 36(64): 627-641. 
Sharif, A. S. M., Islam, S. and Islam, M. (2017). Occurrence and distribution of macrobenthos in relation to physico-chemical parameters in the lower Meghna River estuary, Bangladesh. International Journal of Marine Science, 7(12): 102-113.

Snelgrove, P. V. (1998). The biodiversity of macrofaunal organisms in marine sediments. Biodiversity and Conservation, 7(9): 1123-1132.
Suthar, S., Sharma, J., Chabukdhara, M. and Nema, A. K. (2010). Water quality assessment of river Hindon at Ghaziabad, India: impact of industrial and urban wastewater. Environmental monitoring and assessment, 165(1): 103-112.

Wilhm, J. L. and Dorris, T. C. (1966). Species diversity of benthic macroinvertebrates in a stream receiving domestic and oil refinery effluents. American Midland Naturalist, 427-449 
